\title{
Car and motorcycle deaths: an evolutionary perspective
}

\author{
Mortes por batida de carro e moto: uma perspectiva evolucionista
}

André Luís dos Santos Medeiros ${ }^{1}$

Paulo Nadanovsky ${ }^{1,2}$

${ }^{1}$ Instituto de Medicina Social, Universidade do Estado do Rio de Janeiro. R. São Francisco Xavier 524/Pavilhão João Lyra Filho/7o andar/blocos D e E, Maracanã. 20550-013 Rio de Janeiro RJ Brasil. nadanovsky@ims.uerj.br

${ }^{2}$ Escola Nacional de Saúde Pública, Fundação Oswaldo Cruz. Rio de Janeiro RJ Brasil.

\begin{abstract}
Our aim was to assess differences between men and women in the likelihood of exposure to traffic as drivers of cars and motorcycles, and in the risk of dying from a car or a motorcycle crash, in order to verify the extent to which Darwin's Sexual Selection Theory could have predicted the findings and can help to interpret them. Study population was composed of men and women aged 18 to 60 years residents in the state of Rio de Janeiro between 2004 and 2010, and in the state of Rio Grande do Sul between 2001 and 2010. We built frequency distribution tables and drew bar charts in order to check whether there were differences between the sexes and interactions of sex with age. More men exposed themselves to and died in traffic than women, especially the young. Society should have an especially vigilant attitude towards men on the wheel due to their increased innate tendency to exposure to risk. Darwin's sexual selection theory can be an important ally when postulating hypotheses and interpreting epidemiological findings aiming at improving public policies to reduce the excessive number of traffic deaths, especially in societies where machismo is strong or the stimulus to masculinity is exaggerated.
\end{abstract}

Key words Accidents traffic, Motorcycles, Automobiles, Sex, Biological Evolution
Resumo Objetivamos averiguar diferenças entre homens e mulheres na exposição ao trânsito como motorista de carro e de moto e no risco de morrer por batida desses veículos, para verificar até que ponto a teoria da seleção sexual de Darwin pode predizer os achados e ajudar a interpretá-los. A população de estudo foi composta por homens e mulheres de 18 a 60 anos residentes no Estado do Rio de Janeiro, entre 2004 e 2010, e no Estado do Rio Grande do Sul, entre 2001 e 2010. Elaboramos tabelas de frequência e gráficos de barras para verificar se havia diferenças entre os sexos e interação de sexo com idade. Homens se expuseram e morreram mais no trânsito do que mulheres, especialmente os jovens. A sociedade deveria ter uma atitude especialmente vigilante com homens ao volante devido à tendência inata deles de maior exposição ao risco. A teoria da seleção sexual de Darwin pode ser uma potente aliada na postulação de hipóteses que busquem aperfeiçoar políticas públicas para reduzir a quantidade exagerada de mortes no trânsito, especialmente em sociedades onde o machismo for forte ou o estímulo à masculinidade exagerado.

Palavras-chave Acidentes de trânsito, Motocicletas, Automóveis, Sexo, Evolução biológica 


\section{Introduction}

Everywhere there are more traffic crash deaths among men, especially young, than women ${ }^{1}$. Despite the social, cultural and political explanations presented by gender and masculinities scholars, there is a gap regarding explanations for the origin, i.e. the ultimate cause, of these differences. An attempt to answer this ultimate cause question may point to risk factors, relevant interactions and effective interventions, scarcely or rarely contemplated up to now.

This study, differently from its predecessors ${ }^{1}$, starts with a priori postulated hypotheses on how and why should the risk of dying in a traffic crash (TC) vary according to sex and age. The theoretical basis of our hypotheses, and interpretation of findings, is Darwin's Sexual Selection Theory applied to the study of human behavior, specifically, the "Young Male Syndrome", described ahead.

\section{Risk factors (proximate causes)}

The risk factors, or more proximate causes, of TC deaths include the amount or duration of trips, the mode of transport, the use of safety devices, the natural resistance of the individual and the possibilities of cure ${ }^{2,3}$. Human factors alone, such as reckless behavior, driver's mistakes and sleep at the wheel, are involved in more than $90 \%$ of TCs ${ }^{4,5}$. Drink and driving is one of the main causes of $\mathrm{TCs}^{6-10}$. An increase in speed is associated with both the probability of a crash occurring and of it being severe and the reduction of speed limits may reduce the rate of $\mathrm{TCs}^{9-13}$. The use of seat belts seems to be the more effective way of reducing fatal and non-fatal lesions ${ }^{9,14}$.

\section{Who dies in TCs?}

Men, especially the young, are the main victims of TCs' death everywhere. Among the possible causes for this mortality predominance in young men is the reckless behavior in traffic in addition to an increased use of alcohol ${ }^{1,8-10,15-19}$. Another complementary hypothesis is simply that men drive more. However, even after controlling for distances driven, a large sex difference remains, and this difference depends on age $e^{20,21}$. In any case, increased exposure is also part of the explanation of why they die more.

So, how to explain this discrepancy? If men in fact take more risks by exposing themselves more to and in traffic, there must be a cause for this default behavior.

\section{Darwin's Sexual Selection Theory}

Throughout history, males have been subject to sexual selection through sexual courtship, fights and coercion more than females. This is especially true in mammals, including humans, in whom the demands for pregnancy and lactation reduce the maximum reproduction limit of females ${ }^{22}$. This evolutionary history generated different adaptations in males and females.

Under this perspective, evolutionary psychologists formulated a theory in which men are more prone to dangerous competition and, therefore, risk situations, than women and that this propensity was adaptive as it increased men's fitness (reproductive likelihood) ${ }^{23}$.

\section{The Young Male Syndrome}

"Women are, therefore, from the point of view of sexual selection, a "resource" for which men compete. This competition not necessarily takes place as a direct fight for women. Men may adopt different strategies in this fight, competing for other resources that may be converted into reproductive opportunities, such as political influence and social status, for these resources are directly attractive for women or because they help pacify (or repel) rival men"23.

Several lines of evidence support the conclusion that young men constitute a demographic class specialized by sexual selection for maximum competitive efforts and risk acceptance ${ }^{24,25}$. There is morphological and physiological evidence $^{26}$. Young men seem to be psychologically specialized to embracing danger. In several activities, young men seem to be especially motivated by competition and less discouraged by danger than older men and women ${ }^{27,28}$.

Driving and risky driving may not increase male fitness in the modern environment, but the psychological predispositions that lead modern men to drive more and drive riskily may have been adaptive for our ancestors. For example, overtaking by a man may trigger a risky driving reaction in modern young men and teenagers, who might feel humiliated in this situation. Male teenage drivers were less likely to wear seatbelt, more likely to drink and drive and to be involved in TC, when carrying passengers ${ }^{29}$. On the other hand, middle-aged men, when carrying passengers, especially a woman, were less likely to be involved in a fatal crash - either because in these circumstances they spontaneously drove more carefully in order to protect their women or be- 
cause the women insisted that they drove more carefully $^{29}$.

To show off skills in the form of keen agility and reflexes while speeding may be an "honest" form of advertising value as a sexual partner to the opposite sex and as an able competitor to other men ${ }^{30}$. To exhibit a lack of fear of driving fast, to drive drunk or speaking on the phone could also be ways of advertising prowess even when handicapped ${ }^{30}$.

Women revealed themselves to be more risk averse than men in several activities, including crime, gambling, sexual behavior and drugs and alcohol consumption ${ }^{31}$.

\section{Hypotheses and their rationale}

If men are more competitive and, consequently, more prone to exhibit risky behavior than women, it is expected that they will expose themselves more to traffic as drivers and die more from TC, as these events are related to behaviors such as speeding, drinking and driving, not wearing a seatbelt, exhibitionism, and disrespecting traffic laws. Even when these reckless driving behaviors are not directly exhibited, as is the case for example with many professional drivers and motorcyclists, if driving everyday for long hours is a way of earning an income, more men than women will feel the pressure to earn resources at any price, including risking themselves in traffic for long hours. The individuals who drive a car or a motorcycle are taking risks, provoked either by themselves or by other drivers. If that is a price to pay for some comfort or convenience, it is expected no difference between men and women. However, if in addition to comfort and convenience driving a car or a motorcycle is a way of showing off personal skills, bravery or of earning resources such as an income, in a competition for sexual partners, more men than women will hold licenses to drive cars and especially motorcycles. Additionally, more male drivers will die from a TC, car or motorcycle, than female drivers.

If the main reason why a man competes and, consequently, risks himself, is to obtain sexual access to women (even if unconsciously), the psychological pressure to take risks should lessen, when he already has a woman and a child. There is a higher proportion of married men with children among older men so younger men should take more risks than the older. The younger are trying to obtain resources that older men already have and want to protect; to protect resources already obtained, it is better not to take many risks. Therefore, the difference between the sexes in the exposure to traffic (proportions that hold a license) especially as motorcyclists, and in TC death should be higher among the younger than the older.

Our aim was to assess differences between men and women in the likelihood of exposure to traffic as drivers of cars and motorcycles, and in the risk of dying from a car or a motorcycle crash, in order to verify the extent to which Darwin's Sexual Selection Theory could have predicted the findings and can help to interpret them.

\section{Methods}

\section{Design, settings and population}

We carried out an ecological study with annual sectional secondary data that included men and women aged 18 to 60 years, residents in the states of Rio de Janeiro, between 2004 and 2010, and Rio Grande do Sul, between 2001 and 2010.

\section{Data}

We collated data for car and motorcycle crash deaths, available at Mortality Information System (SIM), from the DATASUS website (www. datasus.gov.br) in January 2012. We compiled the number of inhabitants in each state from the Brazilian Institute of Geography and Statistics $(I B G E)$, available at this same website. Anyone visiting the DATASUS website can directly access the same data used for our study. The exact link to these data is: http://www2.datasus.gov. br/DATASUS/index.php?area=0205. We asked representatives from the 27 Traffic Departments (DETRANS) in Brazil (26 states in Brazil and its capital, Brasília), by e-mail and telephone, about the number of licensed car and motorcycle drivers, by age and sex. Only Rio de Janeiro (RJ) and Rio Grande do Sul (RS) provided these data by sex and age; they provided these data in electronic format, the spreadsheet Excel. We did not seek ethical approval because our research relied exclusively on publicly available information legally accessible to the public and appropriately protected by law through the data guardians, i.e., DATASUS and on secondary use of anonymous information provided by the DETRANS of Rio de Janeiro and of Rio Grande do Sul. These data are not individually identifiable and data linkage does not generate identifiable information. We received the data from DETRANS already in an 
anonymous format; their representatives provided the data without any participant's names or any other form of identification. These representatives from the DETRANS were civil servants who provided the data officially, and made sure that they were allowed to provide such data institutionally. The information collected from the DETRANS' representatives was not publicly available at the time of collection; all of this information is available in the tables of the present article.

\section{Variables}

The four outcome variables were:

- Death in a car crash. Driver or other occupant (International Classification of Disease ICD10, V40 - V49);

- Death in a motorbike crash. Driver or other occupant (ICD 10, V20 - V29);

- License to drive only cars (DETRAN, category B);

- License to drive only bikes or bikes and other vehicles (DETRAN, categories $\mathrm{A}, \mathrm{AB}, \mathrm{AC}, \mathrm{AD}$ and $\mathrm{AE})$.

The two exposure variables were:

- Sex (men and women);

- Age group (18 to 30 and 31 to 60 years).

\section{Data analysis}

The data analyses rationale was to verify the association between sex and the outcomes considering a possible interaction with age. We elaborated frequency tables and bar charts.

We calculated the proportions of the licensed populations to drive car and motorcycle placing on the numerator the number of licensed drivers in the respective categories (DETRAN categories A and B) in RJ and RS, separated by sex and age group, between 2004 and 2010 in RJ and 2001 and 2010 in RS. We placed at the denominator the number of inhabitants in the same classes of sex and age in the referred states then multiplied this ratio by 100 to obtain the number of licensed drivers per 100 inhabitants.

The death to inhabitant ratio in car and motorbike crashes were calculated placing at the numerator the number of car deaths (ICD 10, V40 - V49) and of motorcycle deaths (ICD 10, V20 - V29), respectively, in RJ and RS, categorized by sex and age group, between 2004 and 2010 in RJ, and 2001 and 2010 in RS. We placed at the denominator the number of inhabitants in the same classes of sex and age in the referred states then multiplied this ratio by 100.000 to obtain the number of deaths per 100.000 inhabitants.

We calculated the death to licensed ratio in car and motorcycle crashes placing on the numerator the number of car deaths (ICD 10, V40 - V49) and of motorcycle deaths (ICD 10, V20 - V29), respectively, in RJ and RS, categorized by sex and age group, between 2004 and 2010 in RJ, and 2001 and 2010 in RS. At the denominator we placed the number of licensed drivers to drive only car $(D E$ TRAN, category B) and the number of licensed drivers to drive motorcycles (DETRAN, categories $\mathrm{A}, \mathrm{AB}, \mathrm{AC}, \mathrm{AD}$ and $\mathrm{AE}$ ), respectively, in the same classes of sex and age in the referred states. We multiplied these ratios by 10.000 to obtain the number of deaths per 10.000 licensed to drive only car, and to drive motorcycle.

\section{Results}

The proportion of individuals licensed to drive a car in the population varied from $36.8 \%$ in 31 to 60 year-old men to $13.8 \%$ in 18 to 30 year-old women in RJ (annual average in the years analyzed). Regarding motorcycles, these proportions varied from $31 \%$ in 31 to 60 year-old men in RS to $0.5 \%$ in 18 to 30 year-old women in RJ. The most accentuated differences between the sexes were observed in relation to the proportions licensed to drive motorcycles in RS. The difference between the sexes in relation to license to drive cars was most pronounced in the 18 to 30 age group in RS while in RJ this difference was equivalent in both age groups. The difference between the sexes in relation to license to drive motorcycles was most pronounced in the 31 to 60 yearold age group in RJ while in RS this difference was equivalent in both age groups (Graphic 1, Table 1).

The risk of dying in a car crash in the population varied from 10.3 per 100.000 in 18 to 30 year-old men in RS to 1.6 per 100.000 in 31 to 60 year-old women in RJ (annual average in the years analyzed). In a motorcycle crash, this risk varied from $15.9 \%$ in 18 to 30 year-old men in RJ to $0.4 \%$ in 31 to 60 year-old women in RS. The difference between the sexes was more pronounced in relation to motorcycle than car deaths. Either regarding car or motorcycle deaths the difference between the sexes was larger in the 18 to 30 yearolds (Graphic 2 and Graphic 3, Table 2).

The risk of dying in a car crash in relation to the number of individuals licensed to drive cars varied from 3.8 per 10.000 in 18 to 30 year-old 
Rio Grande do Sul (RS)

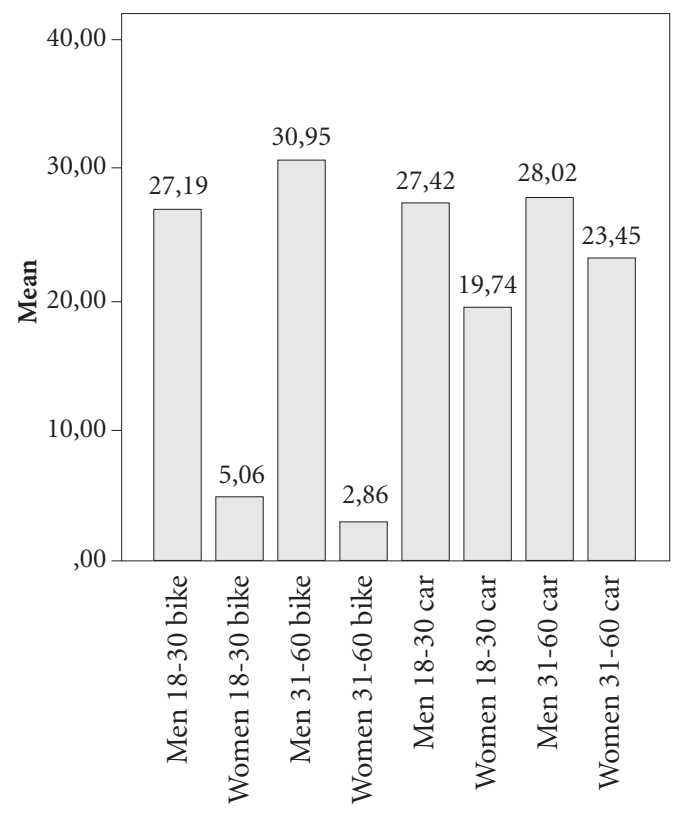

Rio de Janeiro (RJ)

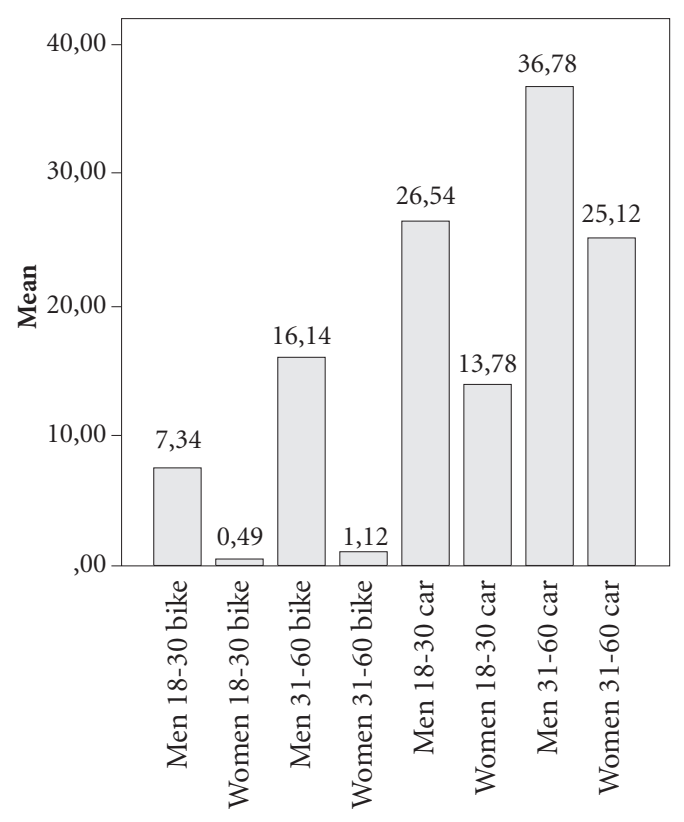

Graphic 1. Proportions (\%) ${ }^{*}$ of the population licensed to drive motorcycle and car, according to sex and agegroup, in the states of Rio Grande do Sul and of Rio de Janeiro.

*Annual averages for the period 2001-2010 in RS and 2004-2010 in RJ, based on Table 1.

men in RS to 0.6 per 10.000 in 31 to 60 year-old women in RJ (annual average in the years analyzed). In a motorcycle crash this risk varied from 38.3 in 18 to 30 year-old women in RJ to 1.3 in 31 to 60 year-old women in RS. In RJ, the risk of dying in a motorcycle crash in relation to the number of individuals of the same sex and ages licensed to drive a motorcycle was higher among women than men in both age groups. The difference between the sexes was more pronounced in relation to motorcycle than car deaths. Either regarding car or motorcycle deaths the difference between the sexes was larger in the 18 to 30 yearolds (Graphic 2 and Graphic 3, Table 2).

\section{Discussion}

Driving seems to be a very risky activity in the two Brazilian states analyzed, but it was not uniformly distributed in these populations. Greater proportions of men than women had license to drive cars. In relation to license to drive motor- cycles, a riskier activity, the proportions of men were markedly greater. The risk of dying in a car or motorcycle crash in the population followed the same pattern of the proportions licensed to drive; much higher risks among men than among women and more accentuated differences between the sexes in the younger age group, especially in relation to death in a motorcycle. Part of this greater risk of dying in TC among men may be, simply, due to greater exposure to traffic (greater proportions of men licensed to drive). For this reason, we thought useful to verify whether beyond this increased risk due to greater exposure, the risk, considering the level of exposure, that is, in relation to the number licensed to drive, would still be higher among men. Again, we found that the risk of dying in a TC, considering the number licensed to drive, was higher among men. Therefore, the increased risk of death among men was not only a consequence of more men being drivers, but also of men's behavior while driving. However, there were two exceptions in these ratios: men and women aged 
Table 1. Population, number licensed to drive and proportion of the population licensed to drive motorcycle and car, according to sex and age-group, in Rio de Janeiro between 2004 and 2010, and in Rio Grande do Sul between 2001 and 2010.

\begin{tabular}{|c|c|c|c|c|c|c|c|c|c|c|c|c|}
\hline \multirow{3}{*}{ Year } & \multicolumn{6}{|c|}{ Men motorcycle Rio de Janeiro } & \multicolumn{6}{|c|}{ Women motorcycle Rio de Janeiro } \\
\hline & \multicolumn{2}{|c|}{$\begin{array}{c}\text { Population } \\
\text { Age-group }\end{array}$} & \multicolumn{2}{|c|}{$\begin{array}{c}\text { Licensed } \\
\text { Age-group }\end{array}$} & \multicolumn{2}{|c|}{$\begin{array}{c}\text { Proportion \% } \\
\text { Age-group }\end{array}$} & \multicolumn{2}{|c|}{$\begin{array}{l}\text { Population } \\
\text { Age-group }\end{array}$} & \multicolumn{2}{|c|}{$\begin{array}{c}\text { Licensed } \\
\text { Age-group }\end{array}$} & \multicolumn{2}{|c|}{$\begin{array}{c}\text { Proportion \% } \\
\text { Age-group }\end{array}$} \\
\hline & $18-29$ & $30-59$ & $18-30$ & $31-60$ & $18-30$ & $31-60$ & $18-29$ & $30-59$ & $18-30$ & $31-60$ & $18-30$ & $31-60$ \\
\hline 04 & 1551333 & 2673560 & 110305 & 407008 & 7.11 & 15.22 & 1605809 & 3013469 & 5882 & 31439 & 0.37 & 1.04 \\
\hline 05 & 1587930 & 2735515 & 109871 & 40811 & 6.92 & 14.92 & 1643480 & 308 & 584 & 315 & 0.36 & 1.02 \\
\hline 2006 & 1606565 & 2767061 & 100522 & 446002 & 6.26 & 16.12 & 1662671 & 3116323 & 5637 & 339 & 0.34 & 1.09 \\
\hline 2007 & 1568507 & 2925256 & 106879 & 464815 & 6.81 & & 1605364 & 3311509 & 6526 & & 0.41 & 1.08 \\
\hline 2008 & 1563093 & 2980047 & 116370 & 487353 & 7.44 & 16.35 & 1596274 & 3369890 & 7982 & 37940 & 0.50 & 1.13 \\
\hline 2009 & 1558132 & 3036901 & 127426 & 513652 & 8.18 & 16.91 & 1588017 & 3431325 & 10252 & 41353 & 0.65 & 1.21 \\
\hline 2010 & 1560945 & 3099097 & 135145 & 543827 & 8.66 & 17.55 & 1603280 & 3487173 & 12703 & 45182 & 0.79 & 1.30 \\
\hline
\end{tabular}

\begin{tabular}{|c|c|c|c|c|c|c|c|c|c|c|c|c|}
\hline \multirow{3}{*}{ Year } & \multicolumn{6}{|c|}{ Men motorcycle Rio Grande do Sul } & \multicolumn{6}{|c|}{ Women motorcycle Rio Grande do Sul } \\
\hline & \multicolumn{2}{|c|}{$\begin{array}{l}\text { Population } \\
\text { Age-group }\end{array}$} & \multicolumn{2}{|c|}{$\begin{array}{l}\text { Licensed } \\
\text { Age-group }\end{array}$} & \multicolumn{2}{|c|}{$\begin{array}{c}\text { Proportion \% } \\
\text { Age-group }\end{array}$} & \multicolumn{2}{|c|}{$\begin{array}{l}\text { Population } \\
\text { Age-group }\end{array}$} & \multicolumn{2}{|c|}{$\begin{array}{l}\text { Licensed } \\
\text { Age-group }\end{array}$} & \multicolumn{2}{|c|}{$\begin{array}{c}\text { Proportion \% } \\
\text { Age-group }\end{array}$} \\
\hline & $18-29$ & $30-59$ & $18-30$ & $31-60$ & $18-30$ & $31-60$ & $18-29$ & $30-59$ & $18-30$ & $31-60$ & $18-30$ & $31-60$ \\
\hline 2001 & 1022989 & 1908220 & 217530 & 515585 & 21.26 & 27.02 & 1016076 & 2015269 & 18971 & 39932 & 1.87 & 1.98 \\
\hline 2002 & 1033194 & 1926346 & 225801 & 542053 & 21.85 & 28.14 & 1026265 & 2034536 & 22418 & 43163 & 2.18 & 2.12 \\
\hline 2003 & 1043867 & 1945136 & 239722 & 569609 & 22.96 & 29.28 & 1036887 & 2054582 & 27489 & 46825 & 2.65 & 2.28 \\
\hline 2004 & 1054436 & 1963903 & 256184 & 584041 & 24.30 & 29.74 & 1047512 & 2074539 & 34275 & 50552 & 3.27 & 2.44 \\
\hline 2005 & 1078495 & 2006511 & 274475 & 608172 & 25.45 & 30.31 & 1071560 & 2119832 & 42425 & 54869 & 3.96 & 2.59 \\
\hline 2006 & 1090781 & 2028180 & 293275 & 633190 & 26.89 & 31.22 & 1083825 & 2142924 & 52535 & 60197 & 4.85 & 2.81 \\
\hline 2007 & 1146729 & 2118289 & 319752 & 662110 & 27.88 & 31.26 & 1120978 & 2240963 & 64641 & 66855 & 5.77 & 2.98 \\
\hline 2008 & 1121077 & 2092021 & 352120 & 691456 & 31.41 & 33.05 & 1093569 & 2210067 & 79195 & 74884 & 7.24 & 3.39 \\
\hline 2009 & 1124165 & 2119853 & 374290 & 721404 & 33.29 & 34.03 & 1094994 & 2237629 & 95422 & 85171 & 8.71 & 3.81 \\
\hline 2010 & 1056207 & 2116746 & 386877 & 750392 & 36.63 & 35.45 & 1052768 & 2247440 & 106113 & 95251 & 10.08 & 4.24 \\
\hline
\end{tabular}

\begin{tabular}{|c|c|c|c|c|c|c|c|c|c|c|c|c|}
\hline \multirow{3}{*}{ Year } & \multicolumn{6}{|c|}{ Men car Rio de Janeiro } & \multicolumn{6}{|c|}{ Women car Rio de Janeiro } \\
\hline & \multicolumn{2}{|c|}{$\begin{array}{c}\text { Population } \\
\text { Age-group }\end{array}$} & \multicolumn{2}{|c|}{$\begin{array}{l}\text { Licensed } \\
\text { Age-group }\end{array}$} & \multicolumn{2}{|c|}{$\begin{array}{c}\text { Proportion \% } \\
\text { Age-group }\end{array}$} & \multicolumn{2}{|c|}{$\begin{array}{l}\text { Population } \\
\text { Age-group }\end{array}$} & \multicolumn{2}{|c|}{$\begin{array}{c}\text { Licensed } \\
\text { Age-group }\end{array}$} & \multicolumn{2}{|c|}{$\begin{array}{c}\text { Proportion \% } \\
\text { Age-group }\end{array}$} \\
\hline & $18-29$ & $30-59$ & $18-30$ & $31-60$ & $18-30$ & $31-60$ & $18-29$ & $30-59$ & $18-30$ & $31-60$ & $18-30$ & $31-60$ \\
\hline 004 & 1551333 & 2673560 & 451924 & 974910 & 29.13 & 36.46 & 1605809 & 3013469 & 231793 & 754569 & 14.43 & 25.04 \\
\hline 005 & 1587930 & 2735515 & 452501 & 9771 & 28.50 & & 16434 & 3081 & 2323 & 756 & 14. & \\
\hline 2006 & 1606565 & 2767061 & 420202 & 1041432 & 26.16 & 37.64 & 1662671 & 3116323 & 214195 & 794047 & 12.88 & 25.48 \\
\hline 2007 & 1568507 & 2925256 & 411594 & 1069016 & 26.24 & 36.54 & 1605364 & 3311509 & 215333 & 817032 & 13.41 & 24.67 \\
\hline 2008 & 1563093 & 2980047 & 404433 & 1095043 & 25.87 & 36.75 & 1596274 & 3369890 & 217907 & 840895 & 13.65 & 24.95 \\
\hline 2009 & 1558132 & 3036901 & 398518 & 1124778 & 25.58 & 37.04 & 1588017 & 3431325 & 224476 & 870143 & 14.14 & 25.36 \\
\hline 2010 & 1560945 & 3099097 & 379864 & 1157022 & 24.34 & 37.33 & 1603280 & 3487173 & 221419 & 900502 & 13.81 & 25.82 \\
\hline
\end{tabular}

\begin{tabular}{|c|c|c|c|c|c|c|c|c|c|c|c|c|}
\hline \multirow{3}{*}{ Year } & \multicolumn{6}{|c|}{ Men car Rio de Janeiro } & \multicolumn{6}{|c|}{ Women car Rio de Janeiro } \\
\hline & \multicolumn{2}{|c|}{$\begin{array}{l}\text { Population } \\
\text { Age-group }\end{array}$} & \multicolumn{2}{|c|}{$\begin{array}{l}\text { Licensed } \\
\text { Age-group }\end{array}$} & \multicolumn{2}{|c|}{$\begin{array}{c}\text { Proportion \% } \\
\text { Age-group }\end{array}$} & \multicolumn{2}{|c|}{$\begin{array}{l}\text { Population } \\
\text { Age-group }\end{array}$} & \multicolumn{2}{|c|}{$\begin{array}{l}\text { Licensed } \\
\text { Age-group }\end{array}$} & \multicolumn{2}{|c|}{$\begin{array}{c}\text { Proportion \% } \\
\text { Age-group }\end{array}$} \\
\hline & $18-29$ & $30-59$ & $18-30$ & $31-60$ & $18-30$ & $31-60$ & $18-29$ & $30-59$ & $18-30$ & $31-60$ & $18-30$ & $31-60$ \\
\hline 2001 & 1022989 & 1908220 & 277762 & 536288 & 27.15 & 28.10 & 1016076 & 2015269 & 177145 & 414885 & 17.43 & 20.59 \\
\hline 2002 & 1033194 & 1926346 & 293375 & 545508 & 28.39 & 28.32 & 1026265 & 2034536 & 188986 & 435461 & 18.41 & 21.40 \\
\hline 2003 & 1043867 & 1945136 & 301117 & 554690 & 28.85 & 28.52 & 1036887 & 2054582 & 198101 & 455926 & 19.11 & 22.19 \\
\hline 2004 & 1054436 & 1963903 & 305602 & 551757 & 28.98 & 28.09 & 1047512 & 2074539 & 205839 & 471464 & 19.65 & 22.73 \\
\hline 2005 & 1078495 & 2006511 & 305011 & 560020 & 28.28 & 27.91 & 1071560 & 2119832 & 209714 & 489036 & 19.57 & 23.07 \\
\hline 2006 & 1090781 & 2028180 & 301043 & 567248 & 27.60 & 27.97 & 1083825 & 2142924 & 212898 & 506557 & 19.64 & 23.64 \\
\hline 2007 & 1146729 & 2118289 & 296870 & 575376 & 25.89 & 27.16 & 1120978 & 2240963 & 216242 & 526062 & 19.29 & 23.47 \\
\hline 2008 & 1121077 & 2092021 & 293131 & 582813 & 26.15 & 27.86 & 1093569 & 2210067 & 222997 & 548530 & 20.39 & 24.82 \\
\hline 2009 & 1124165 & 2119853 & 290963 & 592541 & 25.88 & 27.95 & 1094994 & 2237629 & 234817 & 577220 & 21.44 & 25.80 \\
\hline 2010 & 1056207 & 2116746 & 285912 & 600365 & 27.07 & 28.36 & 1052768 & 2247440 & 236673 & 601681 & 22.48 & 26.77 \\
\hline
\end{tabular}


Table 2. Number of deaths and ratios of the number of deaths per ten thousand licensed to drive (a) and per one hundred thousand inhabitants (b) according to type of vehicle, sex and age-group in Rio de Janeiro between 2004 and 2010 and in Rio Grande do Sul between 2001 and 2010.

\begin{tabular}{|c|c|c|c|c|c|c|c|c|c|c|c|c|}
\hline \multirow{4}{*}{ Year } & \multicolumn{6}{|c|}{ Men car State of Rio Grande do Sul } & \multicolumn{6}{|c|}{ Women car State of Rio Grande do Sul } \\
\hline & \multirow{2}{*}{\multicolumn{2}{|c|}{$\begin{array}{c}\text { Deaths } \\
\text { Age-group }\end{array}$}} & \multicolumn{4}{|c|}{ Ratios Age-group } & \multirow{2}{*}{\multicolumn{2}{|c|}{$\begin{array}{c}\text { Deaths } \\
\text { Age-group }\end{array}$}} & \multicolumn{4}{|c|}{ Ratios Age-group } \\
\hline & & & \multirow{2}{*}{$\begin{array}{c}18-30 \\
\text { a }\end{array}$} & \multirow{2}{*}{$\begin{array}{c}18-30 \\
b\end{array}$} & \multirow{2}{*}{$\begin{array}{c}31-60 \\
a\end{array}$} & \multirow{2}{*}{$\begin{array}{c}31-60 \\
b\end{array}$} & & & \multirow{2}{*}{$\begin{array}{c}18-30 \\
\text { a }\end{array}$} & \multirow{2}{*}{$\begin{array}{c}18-30 \\
b\end{array}$} & \multirow{2}{*}{$\begin{array}{c}31-60 \\
a\end{array}$} & \multirow{2}{*}{$\begin{array}{c}31-60 \\
b\end{array}$} \\
\hline & $18-30$ & $31-60$ & & & & & $18-30$ & $31-60$ & & & & \\
\hline 2001 & 82 & 101 & 2.95 & 8.02 & 1.88 & 5.29 & 20 & 25 & 1.13 & 1.97 & 0.60 & 1.24 \\
\hline 2002 & 96 & 113 & 3.27 & 9.29 & 2.07 & 5.87 & 30 & 38 & 1.59 & 2.92 & 0.87 & 1.87 \\
\hline 2003 & 113 & 117 & 3.75 & 10.83 & 2.11 & 6.02 & 31 & 36 & 1.56 & 2.99 & 0.79 & 1.75 \\
\hline 2004 & 110 & 131 & 3.60 & 10.43 & 2.37 & 6.67 & 20 & 31 & 0.97 & 1.91 & 0.66 & 1.49 \\
\hline 2005 & 115 & 128 & 3.77 & 10.66 & 2.29 & 6.38 & 22 & 33 & 1.05 & 2.05 & 0.67 & 1.56 \\
\hline 2006 & 105 & 132 & 3.49 & 9.63 & 2.33 & 6.51 & 24 & 25 & 1.13 & 2.21 & 0.49 & 1.17 \\
\hline 2007 & 112 & 137 & 3.77 & 9.77 & 2.38 & 6.47 & 20 & 23 & 0.92 & 1.78 & 0.44 & 1.03 \\
\hline 2008 & 117 & 127 & 3.99 & 10.44 & 2.18 & 6.07 & 29 & 38 & 1.30 & 2.65 & 0.69 & 1.72 \\
\hline 2009 & 124 & 153 & 4.26 & 11.03 & 2.58 & 7.22 & 25 & 37 & 1.06 & 2.28 & 0.64 & 1.65 \\
\hline 2010 & 137 & 160 & 4.79 & 12.97 & 2.67 & 7.56 & 28 & 58 & 1.18 & 2.66 & 0.96 & 2.58 \\
\hline \multirow{4}{*}{ Year } & \multicolumn{6}{|c|}{ Men motorcycle State of Rio Grande do Sul } & \multicolumn{6}{|c|}{ Women motorcycle State of Rio Grande do Sul } \\
\hline & & & & Ratios A & ge-grou & & & & & Ratios A & ge-grou & \\
\hline & Age- & oup & $18-30$ & $18-30$ & $31-60$ & $31-60$ & & & $18-30$ & $18-30$ & $31-60$ & $31-60$ \\
\hline & $18-30$ & $31-60$ & a & b & a & b & $18-30$ & $31-60$ & a & b & a & b \\
\hline 2001 & 78 & 36 & 3.59 & 7.62 & 0.70 & 1.89 & 5 & 4 & 2.64 & 0.49 & 1.00 & 0.20 \\
\hline 2002 & 85 & 59 & 3.76 & 8.23 & 1.09 & 3.06 & 14 & 7 & 6.24 & 1.36 & 1.62 & 0.34 \\
\hline 2003 & 104 & 51 & 4.34 & 9.96 & 0.90 & 2.62 & 13 & 5 & 4.73 & 1.25 & 1.07 & 0.24 \\
\hline 2004 & 119 & 97 & 4.65 & 11.29 & 1.66 & 4.94 & 11 & 4 & 3.21 & 1.05 & 0.79 & 0.19 \\
\hline 2005 & 131 & 82 & 4.77 & 12.15 & 1.35 & 4.09 & 9 & 7 & 2.12 & 0.84 & 1.28 & 0.33 \\
\hline 2006 & 140 & 102 & 4.77 & 12.83 & 1.61 & 5.03 & 12 & 13 & 2.28 & 1.11 & 2.16 & 0.61 \\
\hline 2007 & 144 & 99 & 4.50 & 12.56 & 1.50 & 4.67 & 13 & 15 & 2.01 & 1.16 & 2.24 & 0.67 \\
\hline 2008 & 147 & 104 & 4.17 & 13.11 & 1.50 & 4.97 & 27 & 2 & 3.41 & 2.47 & 0.27 & 0.09 \\
\hline 2009 & 185 & 104 & 4.94 & 16.46 & 1.44 & 4.91 & 17 & 11 & 1.78 & 1.55 & 1.29 & 0.49 \\
\hline 2010 & 186 & 120 & 4.81 & 17.61 & 1.60 & 5.67 & 26 & 10 & 2.45 & 2.47 & 1.05 & 0.44 \\
\hline & & Men car & $f D$ & $10 \mathrm{cic}) \mathrm{at}$ & neiro & & & V0110त & ar State & of Rio de & Janeiro & \\
\hline Year & & & & Ratios A & ge-grou & & & & & Ratios A & ge-grou & \\
\hline & Age- & & $18-30$ & $18-30$ & $31-60$ & $31-60$ & & & $18-30$ & $18-30$ & $31-60$ & $31-60$ \\
\hline & 18-30 & $31-60$ & $\mathbf{a}$ & b & $\mathbf{a}$ & b & 18-30 & $31-60$ & $\mathbf{a}$ & b & $\mathbf{a}$ & b \\
\hline 2004 & 141 & 210 & 3.12 & 9.09 & 2.15 & 7.85 & 40 & 67 & 1.73 & 2.49 & 0.89 & 2.22 \\
\hline 2005 & 180 & 223 & 3.98 & 11.34 & 2.28 & 8.15 & 41 & 63 & 1.76 & 2.49 & 0.83 & 2.04 \\
\hline 2006 & 169 & 192 & 4.02 & 10.52 & 1.84 & 6.94 & 51 & 48 & 2.38 & 3.07 & 0.60 & 1.54 \\
\hline 2007 & 148 & 207 & 3.60 & 9.44 & 1.94 & 7.08 & 48 & 63 & 2.23 & 2.99 & 0.77 & 1.90 \\
\hline 2008 & 113 & 172 & 2.79 & 7.23 & 1.57 & 5.77 & 34 & 47 & 1.56 & 2.13 & 0.56 & 1.39 \\
\hline 2009 & 93 & 120 & 2.33 & 5.97 & 1.07 & 3.95 & 27 & 43 & 1.20 & 1.70 & 0.49 & 1.25 \\
\hline 2010 & 97 & 135 & 2.55 & 6.21 & 1.17 & 4.36 & 33 & 28 & 1.49 & 2.06 & 0.31 & 0.80 \\
\hline & Mer & notorcy & le State & of Rio d & e Janeir & & Wor & en mot & rcycle St & ate of $\mathrm{Ri}$ & o de Jan & eiro \\
\hline Year & & & & Ratios A & ge-grou & & & & & Ratios A & ge-grou & \\
\hline & & & $18-30$ & $18-30$ & $31-60$ & $31-60$ & & & $18-30$ & $18-30$ & $31-60$ & $31-60$ \\
\hline & $18-30$ & $31-60$ & $\mathbf{a}$ & b & a & b & $18-30$ & $31-60$ & $\mathbf{a}$ & b & a & b \\
\hline 2004 & 167 & 109 & 15.14 & 10.76 & 2.68 & 4.08 & 15 & 6 & 25.50 & 0.93 & 1.91 & 0.20 \\
\hline 2005 & 209 & 118 & 19.02 & 13.16 & 2.89 & 4.31 & 20 & 13 & 34.24 & 1.22 & 4.12 & 0.42 \\
\hline 2006 & 286 & 140 & 28.45 & 17.80 & 3.14 & 5.06 & 32 & 14 & 56.77 & 1.92 & 4.12 & 0.45 \\
\hline 2007 & 269 & 154 & 25.17 & 17.15 & 3.31 & 5.26 & 35 & 21 & 53.63 & 2.18 & 5.89 & 0.63 \\
\hline 2008 & 306 & 178 & 26.30 & 19.58 & 3.65 & 5.97 & 38 & 18 & 47.61 & 2.38 & 4.74 & 0.53 \\
\hline 2009 & 278 & 171 & 21.82 & 17.84 & 3.33 & 5.63 & 21 & 18 & 20.48 & 1.32 & 4.35 & 0.52 \\
\hline 2010 & 231 & 168 & 17.09 & 14.80 & 3.09 & 5.42 & 38 & 21 & 29.91 & 2.37 & 4.65 & 0.60 \\
\hline
\end{tabular}




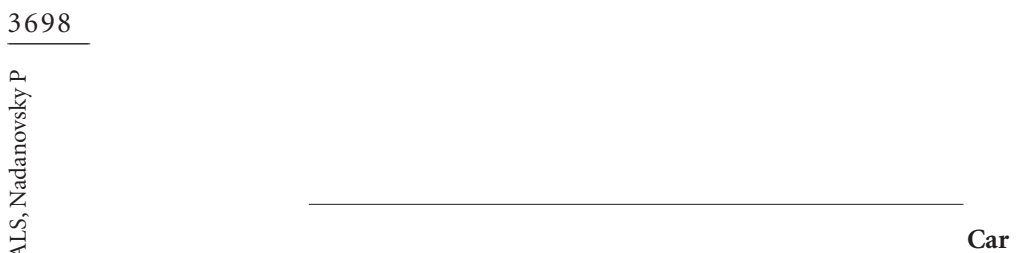

a) Per one hundred thousand inhabitants

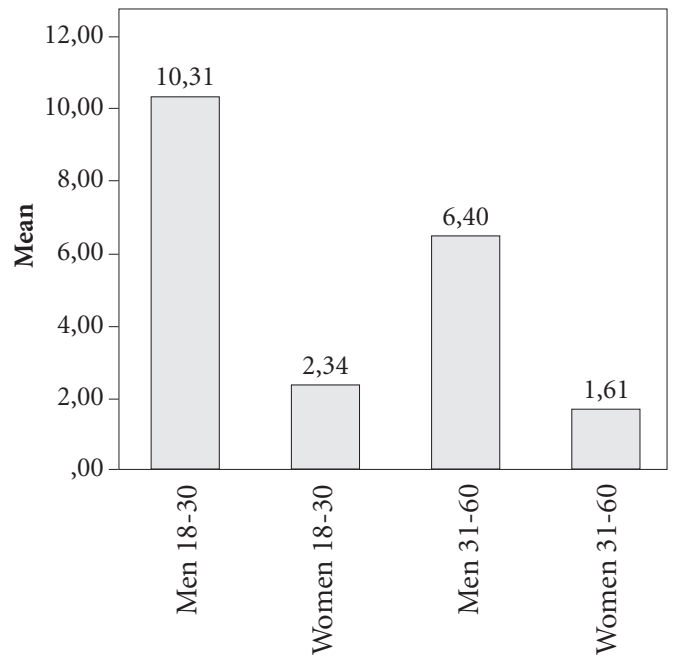

b) Per ten thousand licensed

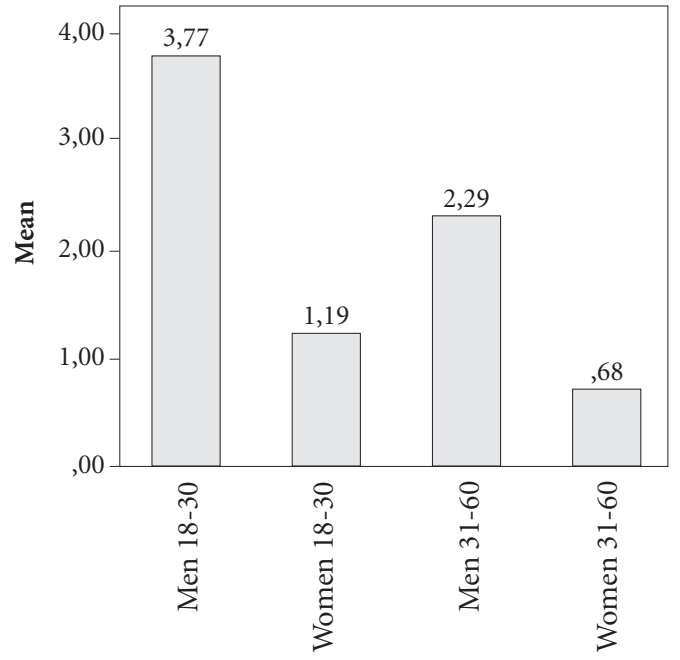

Motorcycle

a) Per one hundred thousand inhabitants

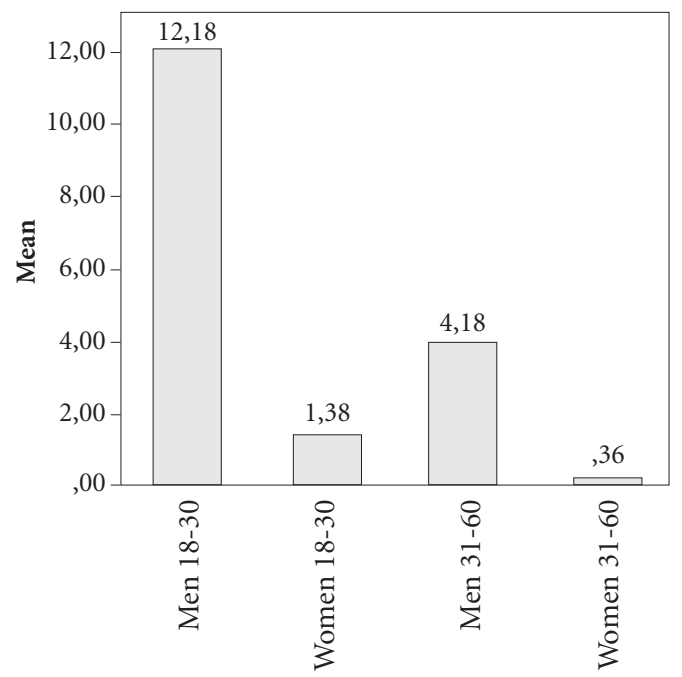

b) Per ten thousand licensed

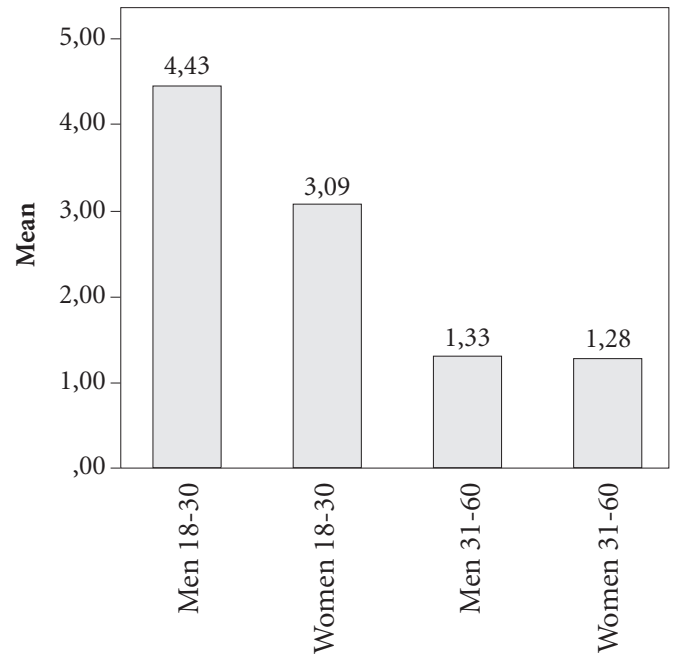

Graphic 2. Ratios* of deaths per one hundred thousand inhabitants (a) and per ten thousand licensed to drive (b) in car and motorcycle crashes in the state of Rio Grande do Sul (RS) according to sex and age-group.

*Annual averages for the period 2001-2010, based on Table 2.

31 to 60 in Rio Grande do Sul presented similar risks of dying in a motorcycle crash, and women in Rio de Janeiro, especially the younger, showed a much higher risk of dying in a motorcycle crash than men in the same State.
The first exception was not a surprise, on the contrary, it was in the expected direction and reinforced the thesis that older men are less competitive and ostentatious of their skills than younger men, therefore, present a more prudent 
Car

a) Per one hundred thousand inhabitants

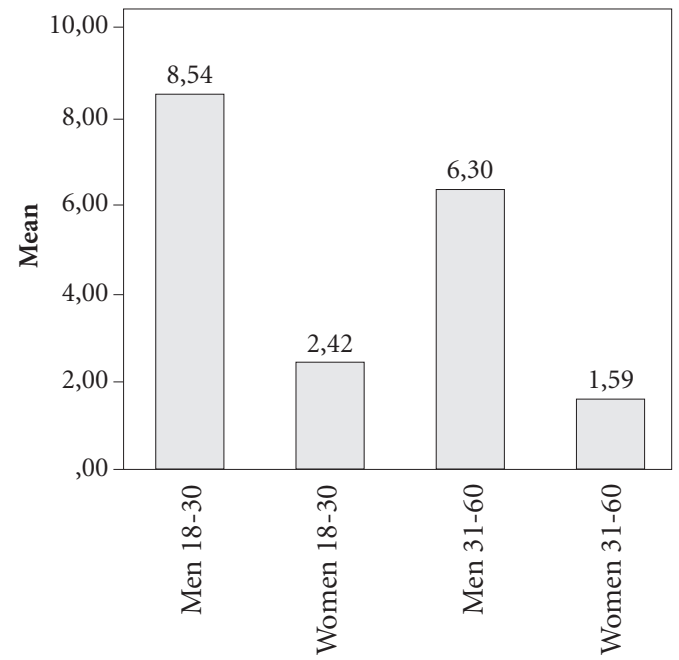

b) Per ten thousand licensed

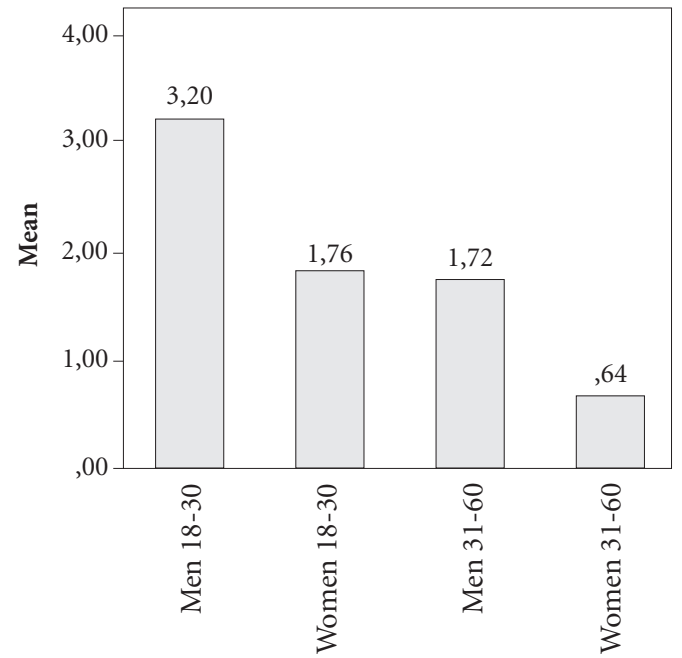

Motorcycle

a) Per one hundred thousand inhabitants

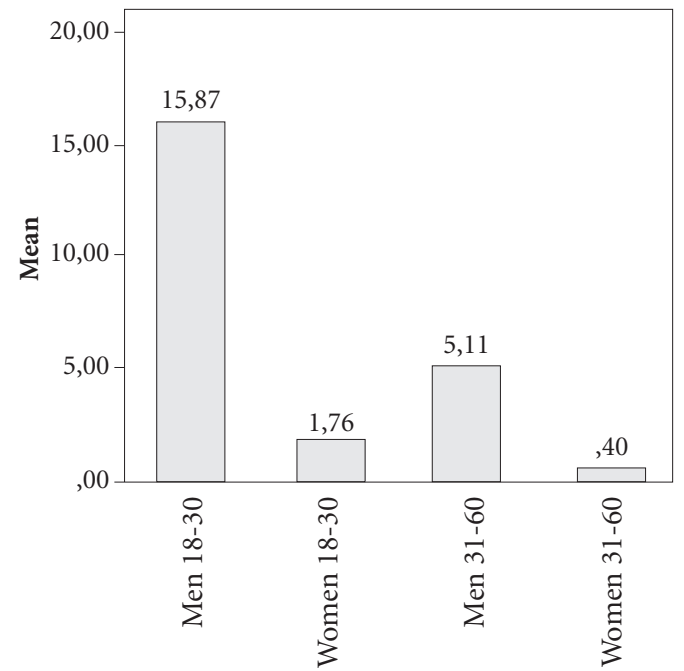

b) Per ten thousand licensed

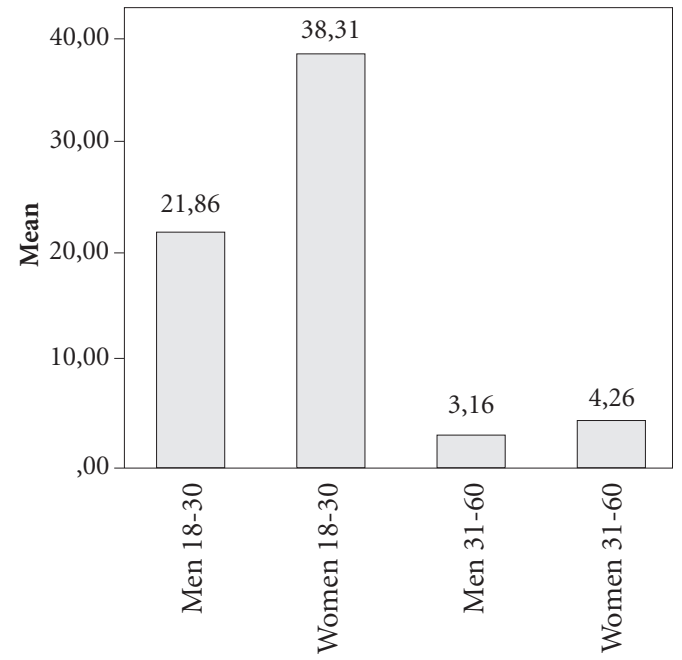

Graphic 3. Ratios* of deaths per one hundred thousand inhabitants (a) and per ten thousand licensed to drive (b) in car and motorcycle crashes in the state of Rio de Janeiro (RJ) according to sex and age-group.

*Annual averages for the period 2004-2010, based on Table 2.

behavior profile, more similar to women. However, the second finding was surprising, apparently refuting the hypothesis that men are more reckless in traffic than women are and, for that, run higher risk of dying.
Therefore, we observed a strong congruency of the findings and the postulated hypothesis; nearly all comparisons suggested that men took more risks than women did, especially the young. However, according to the number licensed to 
drive a motorcycle, women died more frequently than men in Rio de Janeiro. How could we explain this unexpected finding that apparently refuted the postulated hypothesis?

One possibility is that the women in Rio de Janeiro died often not as conductors, but as passengers on the motorcycles; as the number of female registered motorcyclists was very small in Rio, every death of a woman as a passenger in a motorcycle would have a strong artifact influence on this death per registered driver ratio. Another possibility is that women motorcyclists in Rio composed a special group, with higher propensity to risk; traffic in Rio was knowingly so deadly for motorcyclists that only a special few would dare to face it driving a motorcycle (the very small proportion of women licensed to drive motorcycles in Rio reinforces this suspicion). A third possibility is that women, in general, appear to have less spatial abilities than $m^{32}{ }^{32}$, and this skill could be crucial to avoid motorcycle crashes in such difficult driving circumstances as the aggressive traffic in Rio.

One important limitation in our study was that the mortality data did not differentiate conductors from passengers. Therefore, there may be cases in which the conductor was a man, but a woman was a victim as passenger in the car or on the motorcycle and vice-versa. As in the Brazilian culture it is the man who usually drives the vehicle, we presume that it should have been uncommon the situation in which the woman was the driver and the man the victim as a passenger. On the other hand, the inverse should not have been such an uncommon situation; that is, the man driving and the woman being the victim as a passenger. If these assumptions are correct, the deaths of female drivers (based on the number of women licensed to drive) were overestimated in our study.

Another limitation was the small geographical coverage of the data. We tried to obtain data from the 26 States in Brazil and its capital, Brasília, however only Rio de Janeiro and Rio Grande do Sul provided appropriate data. As we did not aim at comparing States or infer about the situation in Brazil as a whole, the analysis, in two States appears to be adequate. Obviously, it is advisable to test this hypothesis in a larger number of populations for it is likely that populations` differences may reveal important interactions.

One advantage of our study was that we obtained information about the number of licensed drivers by age and sex. This made it possible to compare men and women regarding the level of exposure to traffic as drivers and to create an indicator of traffic deaths placing the number of licensed drivers in the denominator.

\section{Implications for public policies}

There are important differences related to the risk of dying and killing in traffic, mainly by sex. Therefore, it may be appropriate to treat these groups differently, especially in societies where machismo is strong ${ }^{23,33}$. Preventive strategies to reduce deaths in traffic should contemplate, mainly, universal measures directed towards the whole population ${ }^{34,35}$, such as to reduce the level of corruption in traffic ${ }^{29}$ and of impunity in general $^{36-38}$, but also, measures directed at specific groups, where risk is increased. Some ideas are the following:

- Training, using cognitive-behavioral techniques, to enable men to avoid aggressive and reckless behavior in traffic, derived from situations in which they take as insults to their masculinity and honor or as opportunities for maleness exhibitionism ${ }^{39}$. Obviously, before instituting this kind of training it is necessary to carry out interventional cost-effectiveness studies;

- Monitoring men's traffic history to apply restrictive sanctions to those who have dangerously broken traffic laws, such as speeding, risky overtaking and tailgating;

- Informing men and women about the risk they take exposing themselves in motorcycles in societies where traffic is highly dangerous, as it was the case in Rio de Janeiro in this study.

Obviously, these are exploratory ideas aiming at initiating a debate and not ready to take prescriptions.

\section{Conclusion}

Our central argument is that drivers and aspiring drivers of the male sex compose a special group, whom society should treat differently in order to cease traffic deaths from being a routine and become sporadic in Brazil and in other countries with similar or higher traffic death rates. Society should have an especially vigilant attitude towards men on the wheel in these countries.

Darwin's sexual selection theory may be a potent ally in postulating hypotheses and interpreting findings that aim at improving public policies to reduce the excessive number of traffic deaths, especially in countries such as Brazil and others where there is accentuated machismo. 


\section{Collaborations}

ALS Medeiros and P Nadanovsky contributed equally to all stages of this study and to the elaboration of the paper.

\section{References}

1. World Health Organization (WHO). Global Status Report on Road Safety: supporting a decade of action. Luxembourg: WHO; 2013.

2. Martin JL, Lafont S, Chiron M, Gadegbeku B, Laumon B. Differences between males and females in traffic accident risk in France. Rev Epidemiol Sante Publique 2004; 52(4):357-367.

3. Bouaoun L, Haddak MM, Amoros E. Road crash fatality rates in France: A comparison of road user types, taking account of travel practices. Accid Anal Prev 2015; 75:217-225.

4. Evans L. The dominant role of driver behavior in traffic safety. Am J Public Health 1996; 86(6):784-786.

5. Petridou E, Moustaki M. Human factors in the causation of road traffic crashes. Eur J Epidemiol 2000; 16(9):819-826.

6. Koizumi MS, Leyton V, Carvalho DG, Coelho CA, Mello Jorge MHP, Gianvecchio V, Gawryzewski VP, Godoy CD, Sinagawa DM, Araújo GL, Muñoz DR. Alcoolemia e mortalidade por acidentes de trânsito no Município de São Paulo, 2007/2008. Revista ABRAMET 2010; 28(1):25-34.

7. Ramstedt M. Alcohol and fatal accidents in the United States - A time series analysis for 1950-2002. Accid Anal Prev 2008; 40(4):1273-1281.

8. World Health Organization (WHO). World report on road traffic injury prevention. Geneva: WHO; 2004.

9. World Health Organization (WHO). Global status report on road safety 2013: supporting a decade of action. Geneva: WHO; 2013.

10. Saldanha RF, Pechansky F, Benzano D, Barros CASM, Boni RB. Differences between attendance in emergency care of male and female victims of traffic accidents in Porto Alegre, Rio Grande do Sul State, Brazil. Cien Saude Colet 2014; 19(9):3925-3929.

11. Aarts L, van Schagen I. Driving speed and the risk of road crashes: A review. Accid Anal Prev 2006; 38(2):215-224.

12. Chris G, Rebecca S, Phil E, Judith G, Ben A, Paul W. Effect of $20 \mathrm{mph}$ traffic speed zones on road injuries in London, 1986-2006: controlled interrupted time series analysis. BMJ 2009; 339:b4469.

13. World Health Organization (WHO). Global status report on road safety: time for action. Geneva: WHO; 2009.

14. Dinh-Zarr TB, Sleet DA, Shults RA, Zaza S, Elder RW, Nichols JL, Thompson RS, Sosin DM. Task Force on Community Preventive Services. Reviews of evidence regarding interventions to increase the use of safety belts. Am J Prev Med 2001; 21(Supl. 4):48-65.

15. Andrade SM, Jorge M. Victims' characteristics by road accidents in a city of Southern Brazil. Rev Saude Publica 2000; 34(2):149-156.

16. Ho R, Gee RY. Young men driving dangerously: Development of the Motives for Dangerous Driving Scale (MDDS). Australian Journal of Psychology 2008; 60(2):91-100.

17. Brasil. Ministério da Saúde (MS). Mortalidade por acidentes de transporte terrestre no Brasil. Brasília: MS; 2007.

18. Tavris DR, Kuhn EM, Layde PM. Age and gender patterns in motor vehicle crash injuries: importance of type of crash and occupant role. Accid Anal Prev 2001; 33(2):167-172. 
19. Vasconcellos E. Urban development and traffic accidents in Brazil. Accid Anal Prev 1999; 31(4):319-328.

20. Massie DL, Campbell KL, Williams AF. Traffic accident involvement rates by driver age and gender. Accid Anal Prev 1995; 27(1):73-87.

21. Massie DL, Green PE, Campbell KL. Crash involvement rates by driver gender and the role of average annual mileage. Accid Anal Prev 1997; 29(5):675-685.

22. Jones D. Evolutionary Psychology. Annual Review of Anthropology 1999; 28:553-575.

23. Wilson M, Daly M. Competitiveness, risk-taking, and violence - The young male syndrome. Ethology and Sociobiology 1985; 6(1):59-73.

24. Baker Junior MD, Maner JK. Risk-taking as a situationally sensitive male mating strategy. Evolution and Human Behavior 2008; 29(6):391-395.

25. Byrnes J, Miller D, Schafer W. Gender Differences in Risk Taking: A Meta-Analysis. Psychol Bull 1999; 125(3):367-383.

26. Daly M, Wilson M. Killing the competition. Human Nature 1990; 1(1):81-107.

27. Bell NJ, Bell RW. Adolescent risk taking. Newbury Park, CA: Sage; 1993.

28. Gove W. The effect of age and gender on deviant behaviour: A biopsychosocial perspective. New York: Aldine; 1985.

29. Vanderbilt T. Traffic: why we drive the way we do (and what it says about us). New York: Vintage Books; 2008.

30. Zahavi A. Mate selection - a selection for a handicap. J Theor Biol 1975; 53(1):205-214.

31. Harrant V, Vaillant NG. Are women less risk averse than men? The effect of impending death on risk-taking behavior. Evolution and Human Behavior 2008; 29(6):396-401.

32. Voyer D, Voyer S, Bryden MP. Magnitude of Sex Differences in Spatial Abilities: A Meta-Analysis and Consideration of Critical Variables. Psychol Bull 1995; 117(2):250-270

33. Daly M, Wilson M. Darwinism and the roots of machismo. Sci Am 1999; 10:8-14.
34. Staton C, Vissoci J, Gong E, Toomey N, Wafula R, Abdelgadir J, Zhou Y, Liu C, Pei F, Zick B, Ratliff C, Rotich C, Jadue N, Andrade L, Isenburg M, Hocker M. Road Traffic Injury Prevention Initiatives: A Systematic Review and Metasummary of Effectiveness in Low and Middle Income Countries. Plos One 2016; 11:1-15 e0144971.

35. Maffei de Andrade S, Soares DA, Matsuo T, Barrancos Liberatti CL, Hiromi Iwakura ML. Road injury-related mortality in a medium-sized Brazilian city after some preventive interventions. Traffic Inj Prev 2008; 9(5):450-455.

36. Castillo-Manzano J, Castro-Nuño M, Fageda X. Are traffic violators criminals? Searching for answers in the experiences of European countries. Transport Policy 2015; 38:86-94.

37. Nadanovsky P, Celeste RK, Wilson M, Daly M. Homicide and impunity: an ecological analysis at state level in Brazil. Rev Saude Publica 2009; 43(5):733-742.

38. Nadanovsky P, Cunha-Cruz J. The relative contribution of income inequality and imprisonment to the variation in homicide rates among Developed (OECD), South and Central American Countries. Soc Sci Med 2009; 69(9):1343-1350.

39. Cohen D, Nisbett RE, Bowdle BF, Schwarz N. Insult, Aggression, and the Southern Culture of Honor: An "Experimental Ethnography". J Pers Soc Psychol 1996; 70(5):945-960.

Artigo apresentado em 29/10/2015

Aprovado em 15/04/2016

Versão final apresentada em 17/04/2016 